\title{
Root Absorption and Xylem Movement of Ethephon in Tomato
}

\author{
William B. Miller \\ Horticulture Section, School of Integrative Plant Science, Cornell University, 134 Plant Science \\ Building, Ithaca, NY 14853 \\ Wanxiang Lu \\ College of Horticulture and Landscape Architecture, Southwest University, Beibei District, \\ Chongqing 400716, P.R. China \\ Dongqin Tang \\ Department of Landscape Architecture, School of Design, Shanghai Jiao Tong University, 800 \\ Dongchuan Road, Shanghai, 200240, P.R. China
}

Additional INDEX words. ethylene, ethylene release, floriculture, plant growth regulators, Solanum lycopersicum

\begin{abstract}
Although ethephon is commonly used as a plant growth regulator during commercial production of horticultural crops, information on its movement within plants is limited. In this study, we developed a method to detect ethephon in plant tissues, and determined ethephon localization and movement using tomato (Solanum lycopersicum L.) as a model system. Tissues were ground in an acidic buffer that preserved ethephon intact. Ethylene was released from the extracts by adding sodium hydroxide and was determined subsequently by gas chromatography. Ethephon was detected in leaves within 1 hour of application to peat-based root zones and within 10 minutes in hydroponics. In a pulse-chase experiment, ethephon levels increased initially, then decreased after the plants were returned to ethephon-free solutions. Ethephon was present in directly collected xylem fluid; fluid collected from petiole stumps (after leaf blade excision) had similar ethephon levels between the different petioles. Stem girdling had no effect on ethephon accumulation in leaves. Together, these data indicate ethephon is readily mobile in the xylem stream and provides insight into the commercial use of ethephon as a root zone-applied growth regulator.
\end{abstract}

Ethephon [(2-chloroethyl) phosphonic acid] is a plant growth regulator (PGR) belonging to the phosphonate family (Abeles et al., 1992). It is absorbed rapidly by aboveground plant parts, and releases ethylene readily at the $\mathrm{pH}$ of most plant tissues. Worldwide, ethephon is the most widely used PGR and is used to inhibit stem elongation, induce abscission of flower buds and leaves, promote branching, promote flowering of pineapple [Ananas comosus (L.) Merr.], and accelerate fruit ripening (Ben-Tal, 1992; Cooke and Randall, 1968; Glady et al., 2007; Leatherwood et al., 2009; Miller and Olberg, 2016; Miller et al., 2012; Starman et al., 2004; Turnbull et al., 1999; Yamaguchi et al., 1971).

The plant growth regulating activity of ethephon is a result of the release of ethylene in plant tissues. Ethephon breakdown products are ethylene, chloride ion, and phosphate ion, and the yield is quantitative (Abeles et al., 1992; Biddle et al., 1976). At a $\mathrm{pH}$ greater than 5, ethephon release occurs rapidly, and is more rapid at warmer temperatures (Cooke and Randall, 1968; Maynard and Swan, 1963; Olien and Bukovac, 1978). Most commonly applied as a foliar spray, ethephon's effect is the

Received for publication 30 July 2021. Accepted for publication 24 Jan. 2022.

Published online 21 February, 2022

We are grateful to the Fred C. Gloeckner Foundation for financial support and to the China Scholarship Council for financial assistance to D.T. and W.L. during their study leaves at Cornell University.

W.L. and D.T. contributed equally to this work and are listed alphabetically. W.B.M. is the corresponding author. E-mail: wbm8@cornell.edu.

This is an open access article distributed under the CC BY-NC-ND license (https://creativecommons.org/licenses/by-nc-nd/4.0/). result of conversion to ethylene in tissues contacted directly by the spray. However, in several systems, at least some ethephon is phloem mobile and moves in a classical source-to-sink manner (Edgerton and Hatch, 1972; Foster et al., 1992; Martin et al., 1972; Puech and Crane, 1975; Weaver et al., 1972; Yamaguchi et al., 1971). In some plants, little if any ethephon movement is seen-for example, in citrus [Citrus sp. (Young and Jahn, 1975)] and mature walnut (Juglans regia L.) leaves (Martin et al., 1972), both of which might be related to difficulty in epidermal passage of mature leaves.

There has been inconsistent interest in the efficacy of ethephon as a root zone-applied PGR (Briggs, 1975; Johnson et al., 1982; Miller and Olberg, 2016; Miller et al., 2012; Tompsett, 1973, 1974). Possibly because of its predominant use as a foliar spray, very few studies on root-zone ethephon uptake and movement in plants have been published, and little is known about xylem mobility of ethephon. Puech and Crane (1975, p. 446) stated that "significant amounts of ethephon are not transported in the xylem," but this statement is based on a lack of xylem translocation resulting from ethephon application to source leaves, not from root-zone uptake.

Kwong and Lagerstedt (1977) demonstrated abscission of bean (Phaseolus vulgaris L.) leaves and stem terminals after root-zone ethephon application, suggesting root absorption and upward movement. Kuo and Chen (1980) found similar effects to flooding (reduced stem elongation, epinasty, adventitious root development) from root-zone ethephon applications in tomato (Solanum lycopersicum) cultivars. Unpublished data of W.B.M. indicate floral abortion (a symptom of ethylene injury) after ethephon root-zone applications in easter lily (Lilium longiflorum 
Thunb.), again suggesting xylem movement. Drennan and Norton (1972) observed that ethephon applied to pea (Pisum sativum L.) split-root systems inhibited nodulation on the treated side, but not on the untreated side. Kawase (1974) found soil-applied ethephon exerted effects on aboveground plant parts of sunflower (Helianthus annuus L.). Although the suggestion for xylem movement is strong, direct evidence is so far lacking.

The purpose of this study was to provide insight into ethephon root uptake, upward movement, and partitioning in plants. To assess ethephon localization, ethephon within harvested tissues or collected xylem sap was converted to ethylene in sealed containers, and the resulting ethylene was measured by gas chromatography.

\section{Materials and Methods}

Plant material. Tomato 'Celebrity' seeds were sown in a soilless peat-based substrate (LM-111; Lambert Peat Moss, Riviere-Ouelle, QC, Canada) and grown in a full-sun glass-glazed greenhouse at $25 / 17^{\circ} \mathrm{C}$ (day/night) temperatures. Unless indicated otherwise, 25 - to 30 -d-old seedlings were transplanted to $10-\mathrm{cm}$ pots filled with soilless substrate (LM-111), then $35-$ to 39-d-old seedlings with five nodes were used in experiments. Leaves and nodes were numbered acropetally.

Hydroponically grown plants were used in Expts. 5 and 6, in which roots of 21-d-old seedlings were washed gently to remove planting mix, and the plants were transferred to a polystyrene foam raft floating in an aerated hydroponic system and grown in a growth chamber (12-h photoperiod, $20^{\circ} \mathrm{C}, 200 \mu \mathrm{mol} \cdot \mathrm{m}^{-2} \cdot \mathrm{s}^{-1}$ photosynthetic photon flux density from cool-white fluorescent lamps). After $10 \mathrm{~d}, 31$-d-old seedlings were used in experiments.

GeNeral TREATMENT AND SAMPLING Methods. For Expts. 1 through 4, intact plants were subirrigated individually with 100 $\mathrm{mL}$ ethephon (Collate; FineAmericas, Walnut Creek, CA) at a concentration of $2000 \mathrm{mg} \cdot \mathrm{L}^{-1}$ ethephon, plus a nonethephon control (100 mL water). Plants were allowed to absorb ethephon solution for indicated times in a greenhouse (as described earlier). For all experiments, irrigation was withheld for $24 \mathrm{~h}$ after ethephon application.

In Expts. 5 and 6, roots of intact hydroponically grown plants were placed in $2000 \mathrm{mg} \cdot \mathrm{L}^{-1}$ ethephon $(800 \mathrm{~mL}$ in a $1.5-\mathrm{L}$ plastic container, five plants per container) in a growth chamber as described earlier. Control plant roots were exposed to water.

ETHYLENE RELEASE FROM PLANT-ABSORBED ETHEPHON. Tissues (typically roots, stems and leaves) were collected at intervals after root-zone ethephon application. Samples were weighed, and 1 -g fresh-weight (FW) samples were ground in $5 \mathrm{~mL}$ sodium acetate buffer $(\mathrm{pH}, 4.5 ; 10 \mathrm{~mm})$ using a mortar and pestle. Acidic buffer was used to prevent decomposition of ethephon. The resulting slurry was transferred into $35-\mathrm{mL}$ glass tubes and capped with a rubber septum. Then, $1 \mathrm{~mL}$ sodium hydroxide $(\mathrm{NaOH} ; 1 \mathrm{M})$ was injected into each tube to convert the ethephon into ethylene gas. Preliminary experiments were conducted to determine the volume of $\mathrm{NaOH}$ needed to force ethephon decomposition and the timing of this phenomena under our conditions. Sodium hydroxide (1 M) was added (1, 2, or $5 \mathrm{~mL}$ ) to the slurry in sealed tubes. Ethylene evolution was followed for $14 \mathrm{~d}$ at $20^{\circ} \mathrm{C}$. Ethylene was measured by withdrawing a 1-mL headspace sample and injecting onto a gas chromatograph equipped for ethylene quantitation.
EXPTS. 1 AND 2: ETHEPHON DISTRIBUTION AFTER ROOT UPTAKE. Tomato seedlings (39 d old) with five leaves were subirrigated with $2000 \mathrm{mg} \cdot \mathrm{L}^{-1}$ ethephon $(0.1 \mathrm{~L}$ per plant). Plants were allowed to absorb the ethephon for $4 \mathrm{~h}$, then were harvested immediately and cut into four parts: roots, stem (subsample composed of $1 \mathrm{~cm}$ stem from immediately above the substrate and 1 $\mathrm{cm}$ from the top of the stem), second leaf from the bottom of the stem, and the two youngest leaves. Tissues were processed as noted earlier. Ethylene was measured $7 \mathrm{~d}$ after adding $\mathrm{NaOH}$. A second experiment was conducted essentially as mentioned here, but with 35-d-old plants, and in this case roots were not harvested.

Expt. 3: Time course of ETHEPhon distribution. Tomato plants were subirrigated with $2000 \mathrm{mg} \cdot \mathrm{L}^{-1}$ ethephon $(0.1 \mathrm{~L}$ per plant) then allowed to continue normal growth in the greenhouse. Small amounts of water were applied to maintain soil moisture at an acceptable level without leaching. At intervals (1-96 h) after treatment, plants were harvested and divided into four parts (1-g FW portions): bottom stem, top stem, "old leaf" (second leaf from the bottom), and the two uppermost, youngest leaves). Tissues were processed as noted earlier. Ethylene was measured $8 \mathrm{~d}$ after adding $\mathrm{NaOH}$ at room temperature.

EXPT. 4: EARLY ABSORPTION. Tomato plants were subirrigated with $2000 \mathrm{mg} \cdot \mathrm{L}^{-1}$ ethephon $(0.1 \mathrm{~L}$ per plant), and plants were allowed to absorb the ethephon for 1 to $8 \mathrm{~h}$. The top two (young) leaves were harvested for analysis and processed as described earlier and ethylene was measured $8 \mathrm{~d}$ after adding $\mathrm{NaOH}$.

Expt. 5: Hydroponics. After $10 \mathrm{~d}$ of establishment in hydroponics, roots were exposed to $2000 \mathrm{mg} \cdot \mathrm{L}^{-1}$ ethephon. After 10 , 20,40 , and $80 \mathrm{~min}$, stem tissue (1-cm segment beneath the second node) and the second leaf were harvested for analysis. Tissues were processed as noted earlier, and ethylene was measured $7 \mathrm{~d}$ after adding $\mathrm{NaOH}$.

Expt. 6. Hydroponic PUlSe chase. Roots of intact plants (as described earlier) were exposed to $2000 \mathrm{mg} \cdot \mathrm{L}^{-1}$ ethephon for 10 min, rinsed gently in tap water, and the plant returned to ethephon-free nutrient solution. After 10, 20, 40, and $80 \mathrm{~min}$, stem and leaf tissues (as described earlier) were harvested for analysis. Tissues were processed as mentioned previously, and ethylene was measured $7 \mathrm{~d}$ after adding $\mathrm{NaOH}$.

EXPT. 7: DIRECT DEMONSTRATION OF ETHEPHON IN XYLEM SAP. To demonstrate directly the presence of ethephon in xylem sap, 35-d-old tomato plants were subirrigated with $0.15 \mathrm{~L}$ of $2000 \mathrm{mg} \cdot \mathrm{L}^{-1}$ ethephon in a growth chamber. One hour after applying the ethephon, plants (five replicates) were decapitated between the cotyledons and first true leaf. A scalpel was used to remove internal stem tissue to form a small "cup" ( $\approx 4 \mathrm{~mm}$ deep) in which xylem exudate accumulated. Exudate was collected for $5 \mathrm{~h}$, pooled into $50 \mathrm{-mL}$ flasks, then $\mathrm{NaOH}$ was added and sealed with an airtight septum. Flasks were held at $20^{\circ} \mathrm{C}$ for $72 \mathrm{~h}$ before ethylene determination.

EXPT. 8: DETERMINATION OF OPTIMAL CONDITIONS FOR ETHYLENE RELEASE FROM ETHEPHON. Ethephon $\left[500 \mu \mathrm{L}\right.$ of $100 \mathrm{mg} \cdot \mathrm{L}^{-1}$ ethephon $(0.346 \mu \mathrm{mol})]$ was added to $473-\mathrm{mL}$ jars, $1 \mathrm{~mL}$ of $1 \mathrm{~N}$ $\mathrm{NaOH}$ was added, and the jars sealed. Jars were held in water baths at $20,30,40$, and $50^{\circ} \mathrm{C}$ for $3 \mathrm{~d}$, and ethylene accumulation measured at intervals by gas chromatography.

EXPT. 9: ETHEPHON MOVEMENT TO DIFFERENT LEAVES IS UNAFFECTED BY STEM HEAT GIRDLING. Half the plants were girdled by directing low-pressure steam through a glass pipet onto the stem immediately above the cotyledons. Plants were treated until 
tissue was visually girdled around the entire stem. After girdling, all plants received $0.15 \mathrm{~L}$ of root-zone ethephon $\left(2000 \mathrm{mg} \cdot \mathrm{L}^{-1}\right)$ by subirrigation. After ethephon treatment, leaves were severed at the base of the blade, leaving the petiole intact. A microcentrifuge tube was attached to each petiole stump to collect exudate over a 3-h period. Ethylene was released from collected exudate by adding $1 \mathrm{~mL}$ of $1 \mathrm{~N} \mathrm{NaOH}$ to the tubes and sealing them into $50-\mathrm{mL}$ erlenmeyer flasks and incubating at $50^{\circ} \mathrm{C}$ overnight. There were eight replicate plants per girdling treatment.

\section{Results}

In preliminary experiments, there was no significant difference between 1, 2, or $5 \mathrm{~mL} \mathrm{NaOH}$ for liberating ethylene from plant tissue (data not shown), indicating $1 \mathrm{~mL} \mathrm{NaOH}$ could be used in future studies. Conversion of ethephon to ethylene was not instantaneous at room temperature. Ethylene accumulated rapidly during the first $24 \mathrm{~h}$ after $\mathrm{NaOH}$ addition, then slowly thereafter to a maximum at 7 to $8 \mathrm{~d}$, where it remained stable or, in some cases, decreased slightly depending on the tissue (data not shown). Essentially no ethylene was released from the extracts in the absence of $\mathrm{NaOH}$. From these preliminary results, addition of $1 \mathrm{~mL} \mathrm{NaOH}$ and an incubation time of 7 to $8 \mathrm{~d}$ was established for liberating ethylene from ethephon in plant tissue slurries. Later experiments with aqueous ethephon were conducted with higher temperatures (described later).

EXPTS. 1 AND 2: ETHEPHON DISTRIBUTION AFTER ROOT UPTAKE. Ethylene release from tissues of nonethephon-treated plants was negligible. In both experiments, the most expanded lower leaves contained the majority (54\% to $59 \%)$ of the ethephon found within the plant (Table 1). Upper expanding leaves had less ( $27 \%$ to $28 \%$ ). Stems contained $11 \%$ to $12 \%$ of the ethephon; and roots (Expt. 1 only), $\approx 8 \%$. Together, these data indicate rapid root entry and upward movement of ethephon.

EXPT. 3: TIME COURSE OF ETHEPHON DISTRIBUTION. Tissues were collected $1 \mathrm{~h}$ to $4 \mathrm{~d}$ after introduction of ethephon into the root zone. After $4 \mathrm{~h}$ of uptake, substantially more ethephon had moved into young and old leaves than in top or bottom stem tissues (Fig. 1). Old leaves released $\approx 19.2-, 6.7-$, and 1.5-fold more ethylene than lower stems, upper stems, and young leaves, respectively. In both old and young leaves, ethephon levels decreased slowly, from $4 \mathrm{~h}$ through $4 \mathrm{~d}$. Ethylene release peaked in stem tissues within $1 \mathrm{~d}$ of ethephon application, although in lower stems there was a small increase through day 2 , then was constant thereafter.

EXPT. 4: EARLy ABSORPTion. Because Expt. 3 established ethephon movement from roots and accumulation in leaves, an

Table 1. Distribution of ethephon residues immediately after subirrigation of tomato plants with ethephon. ${ }^{z}$

\begin{tabular}{lcc}
\hline & Distribution of ethephon residues $(\% \text { of total })^{\mathrm{y}}$ \\
\cline { 2 - 3 } Tissue & Expt. 1 & Expt. 2 \\
\hline Lower, expanded leaf & 54.0 & 59.1 \\
Young leaves & 27.1 & 28.5 \\
Stem & 11.4 & 12.3 \\
Roots & 7.6 & - \\
Total & 100 & 100
\end{tabular}

${ }^{\mathrm{z}}$ Plants were subirrigated with $2000 \mathrm{mg} \cdot \mathrm{L}^{-1}$ ethephon for $4 \mathrm{~h}$, immediately harvested and processed for ethephon content.

${ }^{\mathrm{y}}$ Means of three (Expt. 1) or five (Expt. 2) replications.

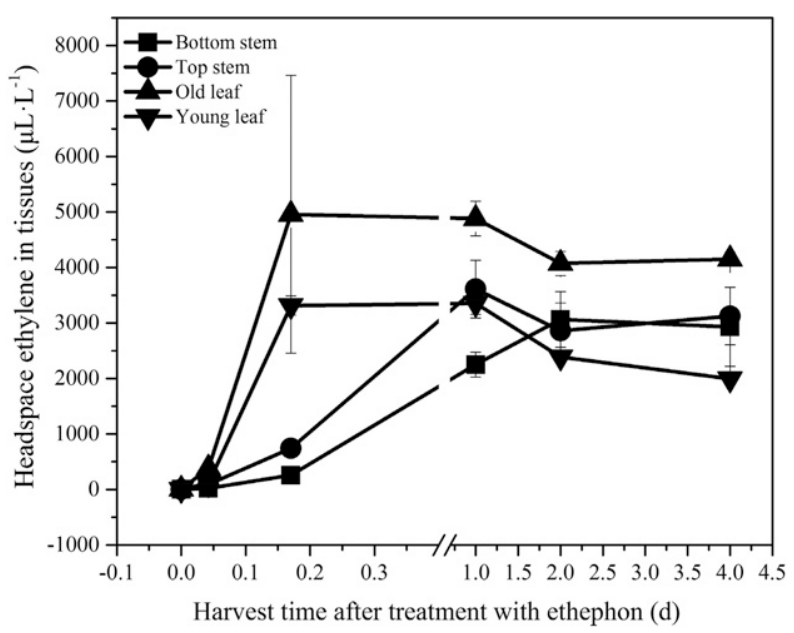

Fig. 1. Time course of ethephon-derived ethylene release in different tissues of tomato after subirrigation with $2000 \mathrm{mg} \cdot \mathrm{L}^{-1}$ ethephon. Plants were sampled $1,4,24,48$, and $96 \mathrm{~h}$ after introducing ethephon into the root zone. In all cases, $1 \mathrm{~g}$ fresh weight of tissue was sampled and processed. Error bars indicate mean $\pm \mathrm{SE}$ of four replicates.

experiment was conducted to determine the pattern of ethephon uptake soon after application. A linear increase $\left(r^{2}=0.9221\right)$ in ethylene release from the upper leaves occurred during the first $8 \mathrm{~h}$ after introduction of ethephon into the root zone (Fig. 2). These data show detectable ethephon movement into upper leaves within $1 \mathrm{~h}$ of adding ethephon to the root zone.

Expt. 5: Hydroponics. Ethephon-derived ethylene was detected in leaves within $10 \mathrm{~min}$ of root exposure to ethephon and increased rapidly thereafter (Fig. 3). Ethylene was released from stems, but the amounts were much lower than for leaves.

EXPt. 6: Hydroponic PULSE-CHASE. A hydroponic pulsechase experiment, during which roots were exposed to ethephon for $10 \mathrm{~min}$ and plants harvested at different times thereafter, gave a different result than Expt. 5. In both the upper and lower leaves, ethylene evolution increased for just 20 to $40 \mathrm{~min}$ after return to nonethephon hydroponic solution and declined thereafter (Fig. 4). As in previous experiments, ethephon levels were much greater in leaves than in stems (Fig. 4).

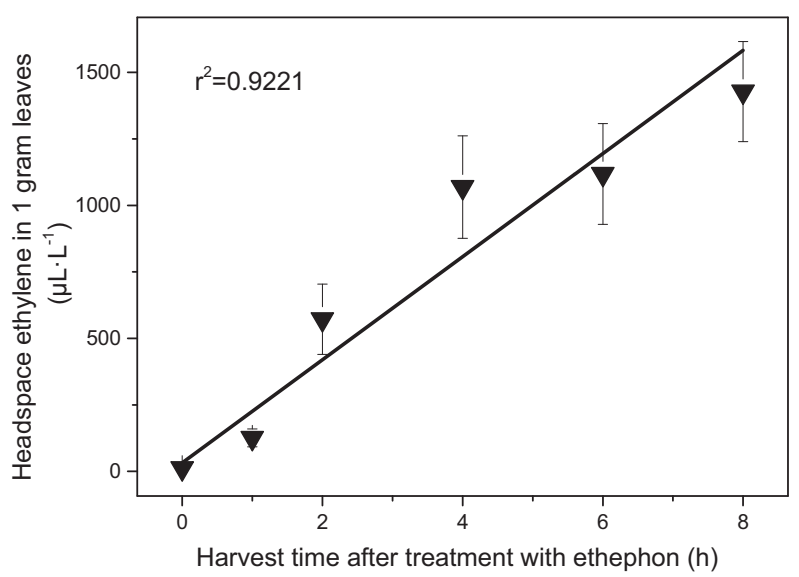

Fig. 2. Ethephon-derived ethylene release from young tomato leaves after subirrigation with $2000 \mathrm{mg} \cdot \mathrm{L}^{-1}$ ethephon solution for 1, 2, 4, 6, and $8 \mathrm{~h}$. Error bars indicate mean $\pm \mathrm{SE}$ of five replicates. 


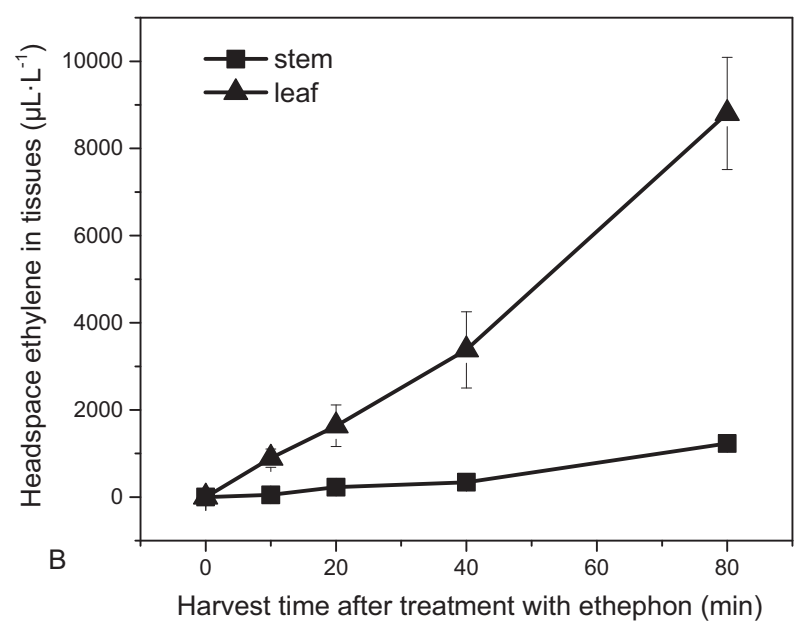

Fig. 3. Ethephon-derived ethylene release in tomato stems and leaves after hydroponic exposure to $2000 \mathrm{mg} \cdot \mathrm{L}^{-1}$ ethephon for $10,20,40$, and $80 \mathrm{~min}$ Error bars indicate mean \pm SE of five replicates.

EXPT. 7: DiRECT DEMONSTRATION OF ETHEPHON IN XYLEM SAP. Xylem sap of decapitated tomato plants exposed previously to root zone ethephon liberated ethylene $\left(44.1 \mu \mathrm{L} \cdot \mathrm{L}^{-1}\right)$, compared with undetectable ethylene seen in xylem sap from control plants.

EXPT. 8: DETERMINATION OF OPTIMAL CONDITIONS FOR ETHYLENE RELEASE FROM ETHEPHON. Temperature influenced profoundly the decomposition of ethephon into ethylene (Fig. 5). Assuming ideal gas behavior, the final ethylene concentration under the conditions of the experiment was calculated to be 16.4 $\mu \mathrm{L} \cdot \mathrm{L}^{-1}$. This concentration was nearly reached in $6.5 \mathrm{~h}$ at $50^{\circ} \mathrm{C}$, by $24 \mathrm{~h}$ for $40^{\circ} \mathrm{C}$, and by $48 \mathrm{~h}$ for $30^{\circ} \mathrm{C}$. The reaction was very slow at $20^{\circ} \mathrm{C}$, when less than $50 \%$ of the theoretical level was reached by $72 \mathrm{~h}$.

EXPT. 9: ETHEPHON MOVEMENT TO DIFFERENT LEAVES IS UNAFFECTED BY STEM HEAT GIRDLING. There was no difference in ethylene evolved from xylem sap collected from girdled or ungirdled plants (data not shown). Girdling had no effect on the volume of sap collected from the five petioles; therefore, data of

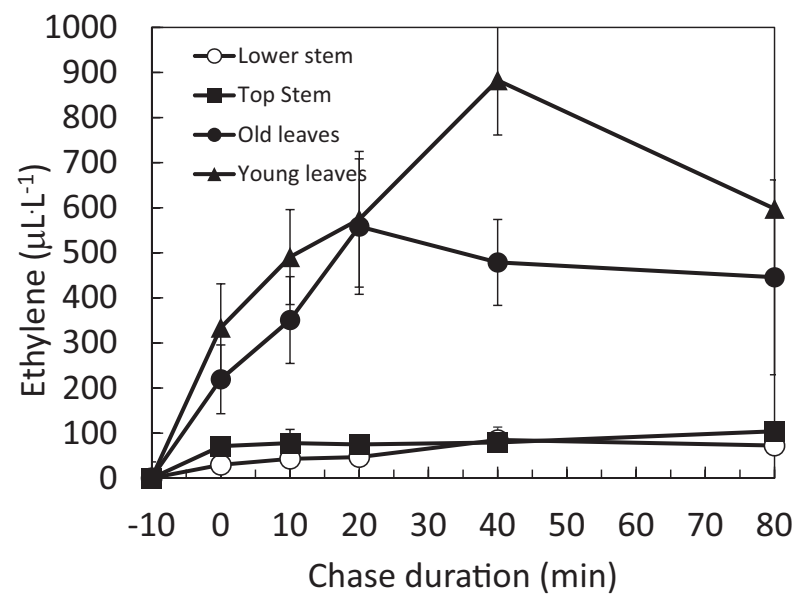

Fig. 4. Ethephon-derived ethylene release in tomato stems and leaves after a 10 -min root-zone pulse of $2000 \mathrm{mg} \cdot \mathrm{L}^{-1}$ ethephon solution in hydroponics After ethephon treatment, roots were washed briefly in distilled water and returned to normal hydroponic solution (time 0 ). Plants were then harvested after 10, 20, 40, or $80 \mathrm{~min}$. Error bars indicate mean $\pm \mathrm{SE}$ of five replicates.

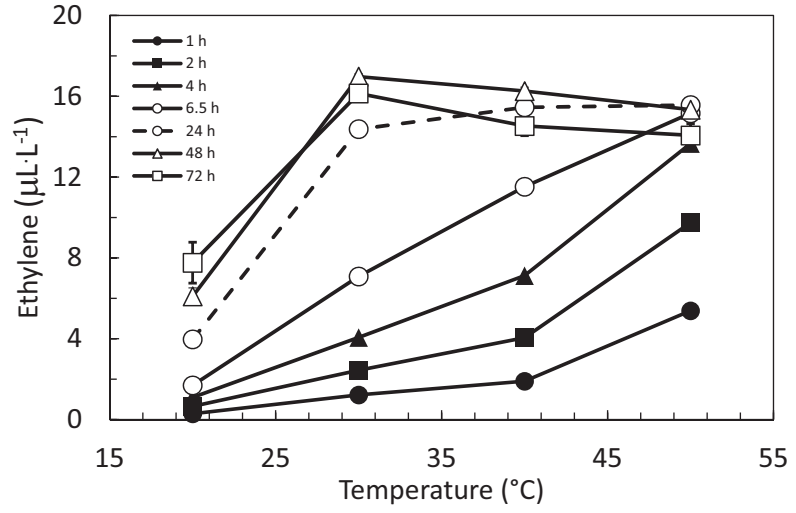

Fig. 5. Effect of temperature and reaction time on conversion of ethephon to ethylene. The expected ethylene concentration from the quantity of ethephon used was $16.4 \mathrm{mg} \cdot \mathrm{L}^{-1}$. Means of five replicates. Error bars are not shown because most fell within the dimension of the symbol used for plotting.

girdled and ungirdled plants were combined. The volume of exuded sap was least in the basal petioles $(0.36 \mathrm{~mL})$, was significantly different from the middle three petioles $(0.80 \mathrm{~mL})$, but was not different from the acropetal petioles $(0.62 \mathrm{~mL})$. After the addition of $\mathrm{NaOH}$ and incubation to release ethylene, there was no difference between the petioles in the ethylene released from the collected xylem sap (average, $3.8 \mu \mathrm{L} \cdot \mathrm{L}^{-1}$ ). To get a proxy of the "concentration" of ethephon in the exuded sap, the concentration of the evolved ethylene was divided by the volume of collected sap. Analysis of variance of the resulting value of microliters per liter ethylene produced per milliliter xylem sap indicated no difference between the petioles (average, $5.7 \mu \mathrm{L} \cdot \mathrm{L}^{-1}$ ).

\section{Discussion}

The literature on ethephon movement in plants has been limited by the paradigm of spray applications, and most research to date has been concerned with whether ethephon is translocated, presumably by phloem, from source leaves to various sinks (younger leaves, adjacent fruit), particularly in the context of fruit abscission (Edgerton and Hatch, 1972; Foster et al., 1992; Martin et al., 1972; Puech and Crane, 1975; Weaver et al., 1972; Yamaguchi et al., 1971). There has been relatively little consideration of substrate application of ethephon (Briggs, 1975; Johnson et al., 1982; Miller and Olberg, 2016; Miller et al., 2012; Tompsett, 1973, 1974), and to this point, unequivocal evidence of xylem movement of ethephon has been published.

The data in our work demonstrate collectively that tomato roots absorb ethephon from the root zone in both soilless mix and hydroponic environments, and the ethephon is moved rapidly upward in the xylem stream. We used acidic buffer to wetgrind ethephon-containing tissues to eliminate ethephon loss, or collected xylem sap directly. In both cases, we released ethylene from the samples with excess $\mathrm{NaOH}$ and quantitated by gas chromatography. As such, we are equating "high pH-dependent release of ethylene" to ethephon and assume the quantity of ethylene released is proportional to the ethephon that existed in the sample.

Ethephon was detected in aboveground plant parts within $1 \mathrm{~h}$ of application of root-zone ethephon in planting mix (Fig. 2) and within $10 \mathrm{~min}$ in a hydroponic system (Figs. 3 and 4). Consistent with movement in the transpiration stream, ethephon residues 
accumulated rapidly in both the upper and lower leaves (Table 1, Fig. 1). Ethephon accumulation in young leaves was linear over at least the first $8 \mathrm{~h}$ of root-zone exposure (Fig. 2).

After $4 \mathrm{~h}$ of root-zone ethephon exposure, older and younger leaves had accumulated much more ethephon than stems; but, during the ensuing $4 \mathrm{~d}$, the "concentration" of ethephon in stems became similar to that in leaves (Fig. 1). During this time period, in the plant there is both ethephon accumulation and conversion to ethylene, so our data do not provide a complete "budget" of ethephon. However, the data do suggest the dynamic nature of ethephon movement and deposition within the plant. Further insight comes from the hydroponic experiments, in which ethephon accumulated rapidly in leaves then declined in the ensuing 40- to 80-min ethephon-free chase (Figs. 3 and 4), demonstrating the "clearing" of ethephon from the xylem stream (Fig. 4).

Although the assay of ethephon residues in plant tissue suggested the upward movement of ethephon from the root zone, we confirmed ethephon xylem movement by direct collection and assay of xylem sap collected from stem stumps. Upon adding $\mathrm{NaOH}$, xylem sap of plants given root-zone ethephon produced ethylene upon adding $\mathrm{NaOH}$ in a sealed flask. Given the speed with which ethephon is moving in the xylem stream, we hypothesized the ethephon concentration would be identical at each petiole. Experiments in which individual leaves were removed and sap collected from the petioles (which remained attached to the plant) showed differences in sap volume between some of the petioles (data not shown). When the evolved ethylene was normalized to the collected sap volume, the resulting "concentration" of ethephon in the sap (expressed as microliters per liter ethylene evolved per milliliter xylem sap) showed no differences between the petioles, suggesting there was no processing or sequestration of ethephon as it moved in the xylem through the stem to the different petioles. Girdling stems with steam had no effect on ethephon accumulation in xylem sap of individual petioles (Expt. 9).

Although ethephon is commonly used as a foliar spray during the commercial production of numerous horticulture crops, there has been increased research and interest in using ethephon as a root zone-applied PGR (Currey et al., 2016; Miller and Olberg, 2016; Miller et al., 2012). Miller and Olberg (2016) speculated the effects of root-zone ethephon in daffodil (Narcissus pseudonarcissus L.) could conceivably be the result of gaseous ethylene directly inhibiting cell division or elongation in the intercalary meristem region just under the surface of the planting medium. Conversely, abortion on flowers developing well above the substrate surface (Miller and Olberg, 2016; Miller et al., 2012) or leaf abscission and shoot epinasty in weeping fig [Ficus benjamina L. (Johnson et al., 1982)] are suggestive of a mechanism that does not rely on gaseous diffusion. Our work demonstrates that direct upward movement in the xylem does occur and suggests that ethephon effects in greenhouse crops could depend potentially on both spray volume and concentration, given the potential for runoff and direct soil contact leading to root uptake.

\section{Literature Cited}

Abeles, F.B., P.W. Morgan, and M.E. Saltveit, Jr. 1992. Ethylene in plant biology. 2nd ed. Academic Press, London, UK.

Ben-Tal, Y. 1992. Quantification of ethephon requirements for abscission in olive fruits. Plant Growth Regulat. 11:397-403, https://doi. org/10.1007/BF00130648.
Biddle, E., D.G. Kerfoot, Y.H. Kho, and K.E. Russell. 1976. Kinetic studies of the thermal decomposition of 2-chloroethylphosphonic acid in aqueous solution. Plant Physiol. 58:700-702, https://doi.org/ 10.1104/pp.58.5.700.

Briggs, J.B. 1975. The effects on growth and flowering of the chemical growth regulators ethephon on narcissus and tulip. Acta Hort. 47:287-296.

Cooke, A.R. and D.I. Randall. 1968. 2-Haloethanephosphonic acids as ethylene releasing agents for the induction of flowering in pineapples. Nature 218:974-975.

Currey, C.J., K.G. McCabe, and K.J. Walters. 2016. Concentration and timing of ethephon drench applications interact to affect growth and flowering of containerized angelonia and geranium. HortScience 51:1542-1546, https://doi.org/10.21273/HORTSCI11219-16.

Drennan, D.S.H. and C. Norton. 1972. The effect of Ethrel on nodulation in Pisum sativum L. Plant Soil 36:53-57, https://doi.org/10.1007/ BF01373456.

Edgerton, L. and A. Hatch. 1972. Absorption and metabolism of 14C (2-chloroethyl) phosphonic acid in apples and cherries. J. Amer. Soc. Hort. Sci. 97:112-115.

Foster, K.R., D.M. Reid, and R.P. Pharis. 1992. Ethylene biosynthesis and ethephon metabolism and transport in barley. Crop Sci. 32:1345-1352, https://doi.org/10.2135/cropsci1992.0011183X003200 060008x.

Glady, J.E., N.S. Lang, and E.S. Runkle. 2007. Effects of ethephon on stock plant management of Coreopsis verticillata, Dianthus caryophyllus, and Veronica longifolia. HortScience 42:1616-1621, https:// doi.org/10.21273/HORTSCI.42.7.1616.

Johnson, C.R., D.B. McConnell, and J.N. Joiner. 1982. Influence of ethephon and light intensity on growth and acclimation of Ficus benjamina. HortScience 17:614-615.

Kawase, M. 1974. Role of ethylene in induction of flooding damage in sunflower. Physiol. Plant. 31:29-38, https://doi.org/10.1111/j.1399-3054.1974. tb03673.x.

Kuo, C.G. and B.W. Chen. 1980. Physiological responses of tomato cultivars to flooding. J. Amer. Soc. Hort. Sci. 105:751-755.

Kwong, F.Y. and H.B. Lagerstedt. 1977. Translocation of ethephon in beans and peas. J. Amer. Soc. Hort. Sci. 102:437-440.

Leatherwood, W.R., J.M. Dole, and J.E. Faust. 2009. Ethephon residual catalysis on unrooted Impatiens hawkeri cuttings and stock plants. HortScience 44:532-535, https://doi.org/10.21273/hortsci.44.2. 532.

Martin, G., H. Abdel-Gawad, and R. Weaver. 1972. Movement and fate of (2-chloroethyl) phosphonic acid in walnut. J. Amer. Soc. Hort. Sci. 97:51-54.

Maynard, J.A. and J.M. Swan. 1963. Organophosphorus compounds: I. 2-Chloroalkylphosphonic acids as phosphorylating agents. Aust. J. Chem. 16:596-608, https://doi.org/10.1071/CH9630596.

Miller, W.B., N.S. Mattson, X. Xie, D. Xu, C.J. Currey, K.L. Clemens, R.G. Lopez, M. Olrich, and E.S. Runkle. 2012. Ethephon substrate drenches inhibit stem extension of floriculture crops. HortScience 47:1312-1319, https://doi.org/10.21273/HORTSCI.47.9.1312.

Miller, W.B. and M.W. Olberg. 2016. Novel ethephon application methods for Narcissus. HortScience 51:1245-1250, https://doi.org/ 10.21273/HORTSCI11188-16.

Olien, W. and M. Bukovac. 1978. The effect of temperature on rate of ethylene evolution from ethephon and from ethephon-treated leaves of sour cherry. J. Amer. Soc. Hort. Sci. 103:199-202.

Puech, A. and J. Crane. 1975. Translocation of ethephon in fig (Ficus carica L.) shoots. J. Amer. Soc. Hort. Sci. 100:443-446.

Starman, T.W., M.C. Robinson, and K.L. Eixmann. 2004. Efficacy of ethephon on vegetative annuals. HortTechnology 14:83-87, https:// doi.org/10.21273/horttech.14.1.0083.

Tompsett, A.A. 1973. Narcissus pot plants summary. RW 78, p. 83-86. In: Rosewarne Expt. Hort. Sta. 13th Rep.

Tompsett, A.A. 1974. Narcissus summary. RW 110, p. 59-60. In: Rosewarne Expt. Hort. Sta. 13th Rep. 
Turnbull, C., E. Sinclair, K. Anderson, R. Nissen, A. Shorter, and T. Lanham. 1999. Routes of ethephon uptake in pineapple (Ananas comosus) and reasons for failure of flower induction. J. Plant Growth Regulat. 18:145-152, https://doi.org/10.1007/ PL00007062.

Weaver, R.J., H.A. Abdel-Gawad, and G.C. Martin. 1972. Translocation and persistence of 1, 2-14C-(2-chloroethyl)-phosphonic acid (ethephon) in Thompson seedless grapes. Physiol. Plant. 26:13-16, https://doi.org/10.1111/j.1399-3054.1972.tb03538.x.

Yamaguchi, M., C.W. Chu, and S.F. Yang. 1971. Fate of ${ }^{14} \mathrm{C}$ (2-chloroethyl) phosphonic acid in summer squash, cucumber, and tomato. J. Amer. Soc. Hort. Sci. 96:606-609.

Young, R.H. and O. Jahn. 1975. The fate of $1,2-{ }^{14} \mathrm{C}-(2$-chloroethyl)phosphonic acid in citrus. J. Amer. Soc. Hort. Sci. 100:496-499. 